\title{
Amylin gene promoter mutations predispose to Type 2 diabetes in New Zealand Maori
}

\author{
N. R. Poa ${ }^{1,2}$, G. J. S. Cooper ${ }^{1}$, P. F. Edgar ${ }^{2}$ \\ ${ }^{1}$ The Biochemistry and Molecular Biology Group, School of Biological Sciences, University of Auckland, New Zealand \\ ${ }^{2}$ Molecular Psychiatry Research Group, Christchurch School of Medicine, University of Otago, New Zealand
}

\section{Abstract}

Aims/hypothesis. Amylin gene mutations are known to predispose Chinese and Japanese subjects, but not Caucasian subjects, to Type 2 diabetes. New Zealand Maori, who have a high prevalence of Type 2 diabetes, have genetic origins in South East Asia. Amylin gene mutations could therefore predispose New Zealand Maori to Type 2 diabetes.

Methods. The amylin gene was screened for mutations in the proximal promoter region, exons 1 and 2, intron 1 , and coding region of exon 3 by polymerase chain reaction amplification and direct sequencing of 131 Type 2 diabetic Maori patients and 258 non-diabetic Maori control subjects.

Results. We identified three new amylin gene mutations: two mutations in the promoter region $(-215 \mathrm{~T}>\mathrm{G}$ and $-132 \mathrm{G}>\mathrm{A}$ ) and a missense mutation in exon 3 $(\mathrm{Q} 10 \mathrm{R})$. The $-215 \mathrm{~T}>\mathrm{G}$ mutation was observed in
$5.4 \%$ of Type 2 Maori diabetic patients and predisposed the carrier to diabetes with a relative risk of 7.23. The $-215 \mathrm{~T}>\mathrm{G}$ mutation was inherited with a previously described amylin promoter polymorphism $(-230 \mathrm{~A}>\mathrm{C})$ in $3 \%$ of the Maori with Type 2 diabetes, which suggests linkage disequilibrium exists between these two mutations. The $-230 \mathrm{~A}>\mathrm{C}$ polymorphism on its own, however, was not associated with Type 2 diabetes in Maori subjects. The $-132 \mathrm{G}>\mathrm{A}$ and Q10R mutations were both observed in $0.76 \%$ of Type 2 diabetic patients and were absent in non-diabetic subjects.

Conclusion/Interpretation. The amylin gene mutations identified in this study are associated with Type 2 diabetes in 7\% of Maori. Amylin is likely to be an important susceptibility gene for Type 2 diabetes in Maori people. [Diabetologia (2003) 46:574-578]

Keywords Type 2 diabetes, amylin gene, New Zealand, Maori, Caucasian, mutation, polymorphism.
New Zealand Maori, the indigenous people of New Zealand, are descendants from Polynesians that arrived in New Zealand 800 to 1200 years ago and now comprise approximately 15\% (557 700) of the total New Zealand population [1]. The prevalence of Type

Received: 6 August 2002 / Revised: 25 October 2002

Published online: 5 April 2003

(C) Springer-Verlag 2003

Corresponding author: N. R. Poa, Molecular Psychiatry Research Group, Christchurch School of Medicine, University of Otago, New Zealand

E-mail: nicola.poa@chmeds.ac.nz

Abbreviations: AP-1, Activator protein-1; AP-4, activator protein-4; HNF-1, hepatocyte nuclear factor-1; IPF-1, insulin promoter factor- 1 .
2 diabetes in Maori and Caucasian subjects is $10.8 \%$ and $2.9 \%$ respectively, and is, therefore, a major cause of morbidity and mortality in Maori people [2]. It is generally accepted that Type 2 diabetes has major genetic determinants and mutations in a number of genes that have been identified in clinical subsets of Type 2 diabetes and certain ethnic populations. The prevalence of these mutations range from 1 to $15 \%$ in late onset Type 2 diabetes [3]. That disturbed gene function could cause diabetes in Maori people is indicated by the increased rates of Type 2 diabetes, when compared with New Zealand Caucasian subjects, after controlling for age, income and BMI [4]. The clustering of diabetes-related complications, such as nephropathy, in Maori pedigrees also indicates an inherited genetic component [5]. Together this evidence sug- 
gests that Maori have an increased genetic susceptibility to Type 2 diabetes. Despite these findings, screening of the MODY genes, glucokinase and hepatocyte nuclear factor- $1 \alpha(\mathrm{HNF}-1 \alpha)$, in Maori and Pacific Island populations [6], so far have not identified Type 2 diabetes susceptibility genes for Polynesian people.

There is cumulative evidence of Y chromosome [7] and mitochondrial lineage analysis [8] pointing to a genetic origin for Polynesian people in South East Asia. A missense mutation in the amylin gene, S20G, has been shown to predispose Japanese and Chinese $[9,10]$, but not Caucasian populations $[11,12]$ to Type 2 diabetes. This mutation was prevalent in $0.4 \%$ of Chinese and $4.1 \%$ of Japanese patients with late-onset Type 2 diabetes. Amylin is a 37 amino acid polypeptide that is co-secreted with insulin from the pancreatic beta-islet cell in response to nutrient intake [13]. Although its precise function is not known, amylin has been implicated in the regulation of insulin and glucose metabolism. A prominent feature of amylin is its ability to form amyloid fibrils. Extracellular plaques formed from these fibrils have been detected in 70 to $90 \%$ of patients with Type 2 diabetes at autopsy [14]. The ability of intracellular amyloid deposits to evoke specific apoptotic signalling pathways in beta cells is a feature of beta-cell loss in Type 2 diabetes [15]. The S20G mutation occurs in the region necessary for amyloid formation, amino acids 20 to 29 , and increases the fibrillogenic properties of the peptide [16]. Therefore, this enhanced ability for S20G to form amyloid fibrils in vitro, could be a factor in the genesis of Type 2 diabetes in Japanese and Chinese populations.

The genetic origins of New Zealand Maori being in South East Asia along with amylin gene mutations predisposing East Asian populations to Type 2 diabetes, lead us to hypothesise that amylin gene mutations could also be important in Type 2 diabetes in Maori populations. Therefore, we screened for mutations in the protein encoding and $5^{\prime}$ regulatory sequences of the amylin gene in Maori subjects with late-onset Type 2 diabetes.

\section{Subjects and methods}

Subjects. The study population consisted of 131 Maori patients with a clinical diagnosis of Type 2 diabetes and 258 Maori non-diabetic subjects as the control group. The study group was recruited from clinics where they were being treated for diabetes which was diagnosed by the US National Diabetes Data Group criteria (fasting plasma glucose $>126 \mathrm{mg} / \mathrm{dL}$ and a 2-h post glucose load of $>200 \mathrm{mg} / \mathrm{dL}$ ). Non-diabetic control subjects were enrolled from the general public by offering free testing for diabetes and were included if they had $\mathrm{HbA}_{1 \mathrm{c}}$ values of 3.0-6.0\%. The clinical data for subjects are summarised in Table 1. Before carrying out this study informed consent was obtained from each individual as approved by the Auckland ethics committee and local tribes. Ethnicity was recorded according to the 1996 New Zealand census question [17]. Sub-
Table 1. Clinical characteristics for Maori subjects

\begin{tabular}{lcc}
\hline Parameters & $\begin{array}{l}\text { Type 2 } \\
\text { diabetic } \\
\text { patients }\end{array}$ & $\begin{array}{l}\text { Non- } \\
\text { diabetic } \\
\text { controls }\end{array}$ \\
\hline Subjects & 131 & 258 \\
Sex (M/F) & $72 / 59$ & $138 / 120$ \\
Age (years) \pm SD & $57.0 \pm 12.4$ & $61.4 \pm 7.9$ \\
BMI (kg/m $\left.{ }^{2}\right) \pm$ SD & $31.7 \pm 4.4$ & - \\
Age at diagnosis \pm SD & $46.0 \pm 9.2$ & - \\
Duration of diabetes (years) \pm SD & $12.0 \pm 9.7$ & - \\
HbA 1 (\%) \pm SD & $9.5 \pm 1.8$ & $5.7 \pm 0.3$ \\
Treatment (diet/OHA/insulin) & $27 / 35 / 23$ & - \\
Prevalence of obesity & $63 \%$ & - \\
\hline
\end{tabular}

jects were excluded if they identified themselves as Pacific Islanders, Indian or Asian. The Maori subjects who participated in this study were first and second generation Maori or Maori and New Zealand Caucasian.

Methods. Genomic DNA was extracted from peripheral blood leukocytes using the QIAamp DNA Blood Mini kit according to the manufacturers instructions (Qiagen, Valencia, Calif., USA). The proximal promoter region, exon 1, exon 2, intron 1, coding region of exon 3 (approximately $187 \mathrm{bp}$ ) and $130 \mathrm{nu}-$ cleotides following the stop codon, of the amylin gene were amplified by PCR using the following forward and reverse primers: $5^{\prime}$-atcgcaccttgtactccag-3', 5'-atgcccattgcttctcaaat- $3^{\prime}$ for the proximal promoter region, exon 1 and intron $1 ; 5^{\prime}$ ctcttgatttcagtgctgga-3', 5'-ggctgtagttatttgacagt- $3^{\prime}$ for exon 2 ; and $5^{\prime}$-tcacactttgttccatgttac- $3^{\prime}, 5^{\prime}$-aggtatatgtcctagcaac- $3^{\prime}$ for exon 3. Each PCR amplification reaction contained $100 \mathrm{ng}$ of genomic DNA, 0.1 to $0.2 \mu \mathrm{mol} / 1$ each of forward and reverse primers, $0.2 \mathrm{mmol} / \mathrm{l}$ of each $\mathrm{dNTP}, 0.5$ to 1.0 units of Amplitaq DNA Polymerase (Roche Molecular Systems, Nutley, N.J., USA), $10 \mu \mathrm{l}$ of Buffer II $(10 \mathrm{mmol} / 1$ Tris $\mathrm{HCl}, 50 \mathrm{mmol} / \mathrm{l} \mathrm{KCl}$ $\mathrm{pH} 8.3$ ), $1.0-1.5 \mathrm{mmol} / \mathrm{l} \mathrm{MgCl}_{2}$, and $\mathrm{H}_{2} \mathrm{O}$ to a final volume of $50 \mu$. The reactions were carried out in a Master Gradient (Eppendorf, Hamburg, Germany) thermocycler at $94^{\circ} \mathrm{C}$ for $5 \mathrm{~min}$, $35 \times\left(94^{\circ} \mathrm{C}\right.$ for $0.5 \mathrm{~min}, 55-68^{\circ} \mathrm{C}$ for $1.5 \mathrm{~min}, 68-72^{\circ} \mathrm{C}$ for $1 \mathrm{~min}$ ), 68 to $72^{\circ} \mathrm{C}$ for $5 \mathrm{~min}$. PCR products were enzymatically purified in 0.5 units of shrimp alkaline phosphatase and 0.2 units of Exonuclease I at $37^{\circ} \mathrm{C}$ for $15 \mathrm{~min}$ followed by $80^{\circ} \mathrm{C}$ for $15 \mathrm{~min}$. The PCR products were sequenced on both strands using a BigDye terminator cycle sequencing ready reaction kit (Perkin-Elmer, PE Biosystems Division, Foster City, Calif., USA). Mutations were identified using Sequence Navigator software (Perkin-Elmer).

Analytical methods. Haemoglobin $\mathrm{A}_{1 \mathrm{c}}$ was measured using the Biorad Variant II $\mathrm{HbA}_{1 \mathrm{c}}$ system with a normal range of 4.0 to $6.0 \%$.

Statistics. For statistical analysis, results were presented as means \pm SD. The Fishers Exact test was used to compare frequencies of the $-215 \mathrm{~T}>\mathrm{G}$ mutation. The $2 \times 3$ chi square table was used to compare frequencies of the $-230 \mathrm{~A}>\mathrm{C}$ mutation. Association of both mutations with diabetes was calculated by the McNears test. A $p$ value of less than 0.05 was considered statistically significant. Relative risk was estimated using odds ratios, and $95 \%$ confidence limits were calculated. 


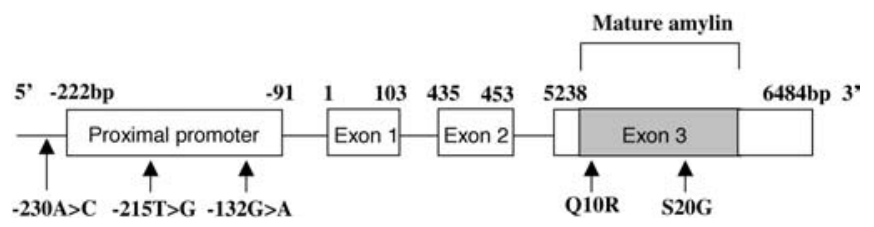

Fig. 1. Locations of amylin gene mutations associated with Type 2 diabetes in Maori $(-215 \mathrm{~T}>\mathrm{G},-132 \mathrm{G}>\mathrm{A}$ and $\mathrm{Q} 10 \mathrm{R})$, and amylin gene mutations not associated with Type 2 diabetes in Maori (-230A $>$ C and S20G), indicated by arrows

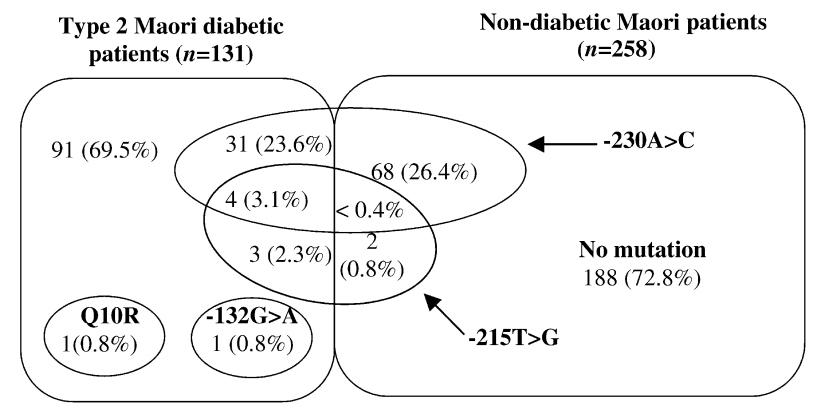

Fig. 2. The prevalence of amylin gene mutations among Maori patients. Mutation $x(y \%)$ where $x$ is the number of individuals with a mutation and $y \%$ is $x / n \times 100$, where $n$ is the total number of Type 2 diabetic and non-diabetic patients screened for mutations

\section{Results}

We identified three new mutations in the amylin gene: two mutations in the proximal promoter region, $(-215 \mathrm{~T}>\mathrm{G}$ and $-132 \mathrm{G}>\mathrm{A})$, and a $\mathrm{CTG} \rightarrow \mathrm{CCG}$ nucleotide change in exon 3 predicted to result in a glutamine to arginine substitution in codon 10 (Q10R) (Fig. 1). A previously reported mutation, $-230 \mathrm{~A}>\mathrm{C}$, in the non-coding promoter region was also identified in this population [18]. The genotype frequencies of these mutations are summarised (Fig. 2). The sequences for exons 1 and 2, and intron 1 of the amylin gene in all subjects screened were identical to the published sequence (Genbank accession \#: X68830).

The $-215 \mathrm{~T}>\mathrm{G}$ promoter mutation was observed in seven Type 2 diabetic patients (5.4\%) and two control subjects $(0.76 \%)$ (Fig. 2). All affected subjects were heterozygous for the $-215 \mathrm{~T}>\mathrm{G}$ mutation. The $-215 \mathrm{~T}>\mathrm{G}$ mutation was associated with Type 2 diabetes in this population with an odds ratio of 7.23 , [1.5-35.3], $p=0.008$. Both non-diabetic carriers had BMI's of 24.38 and $25.29 \mathrm{~kg} / \mathrm{m}^{2}$, whereas the average BMI for diabetic carriers was $28 \mathrm{~kg} / \mathrm{m}^{2}+2.5$ (mean+SD). Of the seven Type 2 diabetic patients carrying the $-215 \mathrm{~T}>\mathrm{G}$ mutation, four also had the $-230 \mathrm{~A}>\mathrm{C}$ promoter mutation (Fig. 2). This combination of mutations was not observed together in any of the non-diabetic control subjects. The occurrence of these two mutations together was significant $\left(\chi^{2}=46.7\right.$; $p<0.001)$ and the odds ratio of $-230 \mathrm{~A}>\mathrm{C}$ carriers inheriting the $-215 \mathrm{~T}>\mathrm{G}$ mutation was 2.27 . There was no difference in BMI $(p=0.459)$ and $\mathrm{HbA}_{1 \mathrm{c}}$ values $(p=0.356)$ between subjects carrying both $-215 \mathrm{~T}>\mathrm{G}$ and $-230 \mathrm{~A}>\mathrm{C}$ when compared with $-215 \mathrm{~T}>\mathrm{G}$ only carriers.

The $-132 \mathrm{G}>\mathrm{A}$ mutation was observed in one patient with Type 2 diabetes $(0.76 \%)$ and was absent in the non-diabetic control subjects (Fig. 2). The $-132 \mathrm{G}>\mathrm{A}$ mutation is a heterozygous mutation and results in the deletion of a MwoI restriction enzyme site. The carrier was a 56-year-old woman, diagnosed with Type 2 diabetes at the age of 45 years and treated with insulin. This patient has a BMI of $26.7 \mathrm{~kg} / \mathrm{m}^{2}$ and reported a family history of diabetes. The Q10R mutation was observed in one patient with Type 2 diabetes $(0.76 \%)$ and was absent in the non-diabetic control subjects (Fig. 2). The Q10R missense mutation is a homozygous mutation in exon 3 , and creates a KasI restriction enzyme site. The carrier was a 60year-old woman, diagnosed with Type 2 diabetes at the age of 56 years and treated with insulin. This patient had a BMI of $28.4 \mathrm{~kg} / \mathrm{m}^{2}$ and reported a family history of diabetes. The association of $-132 \mathrm{G}>\mathrm{A}$ and Q10R mutations with Type 2 diabetes was not statistically significant.

The $-230 \mathrm{~A}>\mathrm{C}$ mutation was observed in both the heterozygous and homozygous state. The frequency of this mutation in patients with Type 2 diabetes and the control group was $26.4 \%$ and $24 \%$ respectively (odds ratio $=1.02,[0.63-1.64], p=0.94)$ and is therefore not associated with Type 2 diabetes in this population (Table 1).

To determine whether the mutations identified in this study disrupt the binding site for transcription factors, potential binding sites in the vicinity of these mutations were screened for using the MatInspector program on the TRANSFAC 4.0 database [19]. The $-215 \mathrm{~T}>\mathrm{G}$ mutation was found in the binding site for the activator protein-1, AP-1, transcription factor $(-217 /-207 \mathrm{bp})$. Both the $-230 \mathrm{~A}>\mathrm{C}$ and $-132 \mathrm{G}>\mathrm{A}$ mutations affected the flanking sequences for an AP-4 putative binding site in the reverse orientation (Fig. 1). The $-132 \mathrm{G}>\mathrm{A}$ mutation also lies within the flanking sequence of another AP-1 potential binding site.

\section{Discussion}

The amylin gene mutations identified in this study are associated with $7 \%$ of Type 2 diabetes in Maori people. The $-215 \mathrm{~T}>\mathrm{G}$ mutation was present at a frequency of $5.4 \%$ and $0.76 \%$ in Type 2 diabetic and non-diabetic Maori subjects respectively. This mutation was therefore associated with Type 2 diabetes in this population $(p=0.008)$ predisposing the carriers to Type 2 diabetes with a relative risk of 7.23. The non-diabetic carriers for the $-215 \mathrm{~T}>\mathrm{G}$ mutation had healthy BMI's, whereas the average BMI for diabetic carriers at 
$28 \mathrm{~kg} / \mathrm{m}^{2} \pm 2.5$ classed them as overweight. Therefore a low BMI couldbe an important factor for maintaining normoglycaemia in these subjects. However, the statistical significance for differences in BMI was unable to be calculated due to the lack of BMI data for the control group in this study.

The $-215 \mathrm{~T}>\mathrm{G}$ mutation was observed in combination with the $-230 \mathrm{~A}>\mathrm{C}$ mutation in $3.1 \%$ of patients with Type 2 diabetes. The occurrence of $-215 \mathrm{~T}>\mathrm{G}$ and $-230 \mathrm{~A}>\mathrm{C}$ mutations together was greater than that due to chance $(p<0.001)$ and suggests linkage disequilibrium exists between these two mutations. Thus it is necessary to test for both the $-215 \mathrm{~T}>\mathrm{G}$ and $-230 \mathrm{~A}>\mathrm{C}$ amylin gene mutations together in future population screenings. The inheritance of two or more diabetes susceptibility markers together, has been reported in the genes encoding IPF-1, HNF-1 $\alpha$ and islet brain-1 (IB-1) $[21,22]$. Subjects who inherited both markers had a more severe form of diabetes compared with those carrying IPF-1, IB-1 or HNF-1 $\alpha$ mutations alone. This suggests a nearby mutation that is in linkage disequilibrium with a known diabetogenic gene which could contribute to the polygenic nature of Type 2 diabetes.

The $-230 \mathrm{~A}>\mathrm{C}$ amylin gene polymorphism has been identified in a Japanese diabetic subject with marked islet amyloid deposition [18]. However, no association of this mutation and Type 2 diabetes was found in a larger Japanese cohort [20]. We also found that there was no difference in frequency of the $-230 \mathrm{~A}>\mathrm{C}$ allele between patients with Type 2 diabetes and the control Maori group, indicating that on its own, the $-230 \mathrm{~A}>\mathrm{C}$ mutation is not likely to be associated with Type 2 diabetes in Maori people. This allele was present in $24 \%$ of Maori and $60 \%$ of Japanese subjects with Type 2 diabetes. However, the differences in frequency between these two populations is not likely to be statistically significant due to the relatively small sample size tested in the Japanese study $(n=35$ diabetic patients and 49 control subjects).

The $-132 \mathrm{G}>\mathrm{A}$ mutation is rare in this population $(0.76 \%)$. The carrier reported a family history of Type 2 diabetes in first-degree relatives, therefore co-segregation of the $-132 \mathrm{G}>\mathrm{A}$ mutation with diabetes should be tested in family members of this carrier. Alternatively, functional studies of this mutation could validate its association with Type 2 diabetes.

All the promoter amylin gene mutations identified were found in putative transcription factor binding sites within or near the proximal promoter region ( -222 and -91 base pairs), which is required for isletspecific transcriptional activity [23]. Thus it would be of interest to investigate whether these mutations alter basal transcriptional level of the amylin gene in pancreatic beta cells.

The Q10R mutation was observed in one patient with Type 2 diabetes indicating that this mutation is rare in Maori people $(0.76 \%)$. The carrier reported a family history of Type 2 diabetes in first-degree rela- tives, therefore it has yet to be determined whether Q10R co-segregates with diabetes in this family. The Q10R mutation does not occur in the region responsible for fibril formation (amino acids 20 to 29) [24], that has been proposed to contribute to the cytotoxic and amyloidogenic properties of amylin. Therefore it is not likely to contribute to the pathogenesis of Type 2 diabetes through enhanced fibril formation.

The amylin gene coding region mutation, S20G, reported in Japanese and Chinese populations [9, 10], was not observed in Maori patients or control subjects and is therefore not likely to be a major contributing factor for Type 2 diabetes in Maori people despite evidence for a common genetic origin for these populations $[7,8]$.

In summary, we found that approximately $7 \%$ of Maori with Type 2 diabetes have mutations in the promoter region of the amylin gene while only $0.8 \%$ Maori without Type 2 diabetes have these mutations. The $-215 \mathrm{~T}>\mathrm{G}$ is associated with increased Type 2 diabetes susceptibility, with a relative risk of 7.23 , and could be linked with the previously described amylin promoter polymorphism, $-230 \mathrm{~A}>\mathrm{C}$. These results suggest that amylin gene mutations may be an important contributor to the polygenic nature of Type 2 diabetes in Maori people.

Acknowledgements. We wish to thank Nga Puhi and Tainui iwi, hapu and whanau (tribes, sub-tribes and families) for their willingness to participate and support this study; Dr. T. Birch, N. Neho, from Hokianga Health, and Dr. D. Gilgen for assisting with recruiting patients and collecting blood samples; T. Ellison and The Hepatitis Foundation for providing non-diabetic blood samples and measuring $\mathrm{HbA}_{1 \mathrm{c}}$ values; and $\mathrm{Dr} \mathrm{C}$. Frampton for statistical analysis. This study was supported by grants from the Health Research Council of New Zealand.

\section{References}

1. NZHIS (1997) Mortality and demographic data 1997. NZHIS Wellington

2. Simmons D, Gatland B, Fleming C, Leakehe L, Scragg R (1994) Prevalence of known diabetes in a multiethnic community. N Z Med J 107:219-222

3. Jun H-E, Bae HY, Lee BR et al. (1999) Pathogenesis of non-insulin-dependent (type 2) diabetes mellitus (NIDDM) - genetic predisposition and metabolic abnormalities. Adv Drug Del Rev 35:157-177

4. Scragg R, Baker J, Metcalf P (1991) Prevalence of diabetes mellitus and impaired glucose tolerance in a New Zealand multiracial workforce. N Z Med J 104:395-397

5. Simmons D, Shaw LM, Scott DJ, Kenealy T, Scragg RK (1994) Diabetic nephropathy and microalbuminuria in the community. The South Auckland Diabetes Survey. Diabetes Care 17:1404-1410

6. Shaw JT, Lovelock PK, Kesting JB et al. (1998) Novel susceptibility gene for late-onset NIDDM is localized to human chromosome 12q. Diabetes 47:1793-1796

7. Su B, Jin L, Underhill P et al. (2000). Polynesian origins: insights from the Y chromosome. Proc Natl Acad Sci USA 97:8225-8228 
8. Lum JK, Cann RL (2000) mtDNA lineage analyses: origins and migrations of Micronesians and Polynesians. Am J Phys Anthropol 113:151-168

9. Sakagashira S, Sanke T, Hanabusa T et al. (1996) Missense mutation of amylin gene (S20G) in Japanese NIDDM patients. Diabetes 45:1279-1281

10. Lee SC, Hashim Y, Li JK et al. (2001) The islet amyloid polypeptide (amylin) gene S20G mutation in Chinese subjects: evidence for associations with type 2 diabetes and cholesterol levels. Clin Endocrinol (Oxf) 54:541-546

11. Birch CL, Fagan LJ, Armstrong MJ, Turnbull DM, Walker M (1997) The S20G islet-associated polypeptide gene mutation in familial NIDDM. Diabetologia 40:1113

12. Hart LM, Stolk RP, Dekker JM et al. (1999) Prevalence of variants in candidate genes for type 2 diabetes mellitus in The Netherlands: the Rotterdam study and the Hoorn study. J Clin Endocrinol Metab 8:1002-1006

13. Cooper GJ, Willis AC, Clark A, Turner RC, Sim RB, Reid KB (1987) Purification and characterization of a peptide from amyloid-rich pancreases of type 2 diabetic patients. Proc Natl Acad Sci USA 84:8628-8632

14. Clark A, Koning EJ de, Hattersley AT, Hansen BC, Yajnik CS, Pouton J (1995) Pancreatic pathology in non-insulindependent diabetes (NIDDM).Diabetes Res Clin Pract [Suppl] 28:S39-S47

15. Hiddinga HJ, Eberhardt NL (1999) Intracellular amyloidogenesis by human islet amyloid polypeptide induces apoptosis in COS-1 cells. Am J Pathol 154:1077-1088

16. Sakagashira S, Hiddinga HJ, Tateishi K et al. (2000) S20G mutant amylin exhibits increased in vitro amyloidogenicity and increased intracellular cytotoxicity compared to wildtype amylin. Am J Pathol 157:2101-2109

17. NZHIS (1996) Recording patient information: ethnicity. Wellington, NZHIS

18. Kajio H, Kobayashi T, Hara M et al. (1992) Islet amyloid polypeptide (IAPP) gene analysis in a Japanese diabetic with marked islet amyloid deposition. Diabetes Res Clin Pract 15:45-48

19. Wingender E, Chen X, Hehl R et al. (2000) TRANSFAC: an integrated system for gene expression regulation. Nucleic Acids Res 28:316-319

20. Tokoyama Y, Kanatsuke A, Suzuki Y et al. (1994) Islet amyloid polypeptide: no evidence of abnormal promoter region in thirty five type 2 diabetic patients. Diabetes Res Clin Pract 22:99-105

21. Hani EH, Stoffers DA, Chevre JC et al. (1999) Defective mutations in the insulin promoter factor-1 (IPF-1) gene in lateonset type 2 diabetes mellitus. J Clin Invest 104:R41-R48

22. Weng J, Macfarlane WM, Lehto M et al. (2001) Functional consequences of mutations in the MODY4 gene (IPF-1) and coexistence with MODY3 mutations. Diabetologia 44:249-258

23. Carty MD, Lillquist JS, Peshavaria M, Stein R, Soeller WC (1997) Identification of cis- and trans-active factors regulating human islet amyloid polypeptide gene expression in pancreatic beta-cells. J Biol Chem 272:11986-11993

24. Westermark P, Engstrom U, Johnson KH, Westermark GT, Betsholtz C (1990) Islet amyloid polypeptide: pinpointing amino acid residues linked to amyloid fibril formation. Proc Natl Acad Sci USA 87:5036-5040 